\title{
Developmental Analysis in Korean Children's Speech Production Using Percentage of Consonants Correct and Whole-Word Measurements
}

\author{
Ji-Wan $\mathrm{Ha}^{\mathrm{a}}$, Soo-Jin Kim ${ }^{\mathrm{b}}$, Young Tae Kimc, Moonja Shin ${ }^{\mathrm{d}}$ \\ ${ }^{a}$ Department of Speech Pathology, Daegu University, Gyeongsan, Korea \\ ${ }^{b}$ Department of Communication Disorders, Korea Nazarene University, Cheonan, Korea \\ 'Department of Communication Disorders, Ewha Womans University, Seoul, Korea \\ ${ }^{d}$ Department of Speech-Language Pathology, Chosun University, Gwangju, Korea
}

\author{
Correspondence: Soo-Jin Kim, $\mathrm{PhD}$ \\ Department of Communication Disorders, Korea \\ Nazarene University, 48 Wolbong-ro, Seobuk-gu, \\ Cheonan 31172, Korea \\ Tel: +82-41-570-7978 \\ Fax: $+82-41-570-7846$ \\ E-mail: sjkim@kornu.ac.kr
}

Received: April 21, 2019

Revised: May 17, 2019

Accepted: May 17, 2019

This work was supported by the National Research Foundation of Korea Grant Funded by the Korean Government (No. NRF-2017R1C1B1010913).

\begin{abstract}
Objectives: The purpose of this study is to present a comprehensive model for speech sound development by comparing the results of performance with segmental and wholeword measurements on the data collected for a large number of children by age. Methods: We conducted a word-level test of the Urimal Test of Articulation And Phonolog-2 (UTAP2) for typically developing children from 2 to 7 years of age in Seoul, Gyeonggi-do, Chungcheong-do, Kyongsang-do, Jeolla-do and Jeju-do in Korea. We assessed children's speech production using various measurements of percentage of consonants correct (PCC), percentage of consonants correct-revised (PCC-R), proportion of whole-word proximity (PWP), phonological mean length of utterance (PMLU), and proportion of wholeword correctness (PWC). After dividing the ages into nine groups, we compared the differences in speech production according to gender and age group at each speech index. Results: There was no statistically significant difference in all indicators between sexes, but age differences were significant. PCC and PCC-R significantly increased the index values until the age of 4 years and 11 months old, and the whole-word measurements increased significantly until the age of 5 years and 5 months old. Conclusion: The results of this study are summarized and the following model is proposed for speech sound development: 'production period of speech sound' (age from 1 to early 2), expansion period of the speech sound inventory' (age from late 2 to early 3), 'elaboration period of speech' (age from late 3 to late 4), and 'stabilization period of speech acquisition' (age from early 5 to age 6).
\end{abstract}

Keywords: Speech sound development, UTAP2, PCC, PWC, PMLU, PWP '말소리장애(speech sound disorders)'는 의사소통장애 가운데 말소리 산출에 결함을 보이는 경우로, 유병률이 학령전기 $10 \%$ $25 \%$ 까지 보고됨에 따라 아동기에 나타날 수 있는 가장 빈번한 장 애로 거론되고 있다(American Speech-Language-Hearing Association, n.d.; Bernthal, Bankson, \& Flipsen, 2013). 다른 모든 장애가 그러하듯이 말소리장애에서도 정확한 진단을 내리는 것은 이후 모 든 중재 방향과 치료 절차에 절대적인 영향을 미치는 매우 중요한 임상적 출발점이다. 글자 그대로 말소리장애는 '말소리’의 장애이기 때문에, 말소리를 직접 다루고 있는 언어재활사의 청지각적 판단에
근거하여 진단이 내려진다. 원인을 아는 말소리장애의 경우 뇌병 변, 뇌신경손상, 구개열, 청각장애, 유전병 등 의학적 진단이 일차적 으로 요구되고, 이와 더불어 말소리에도 문제가 있는지를 언어재활 사가 판단한다. 반면 원인을 모르는 말소리장애는 전적으로 언어재 활사의 판단에 근거하여 진단이 내려지기 때문에, 진단 절차는 언 어재활사들에게 더욱 부담이 되는 과정일 수밖에 없다. 때문에 언 어재활사들은 선별검사, 표준화검사, 자발화분석검사, 비공식적 심 층검사, 역동적 진단평가 등 다양한 진단법 중 대상자에게 적절한 방법을 선택하여 보다 신뢰할 수 있는 진단결과를 얻기 위해 노력 
한다. 이 가운데 가장 널리 사용되는 진단방법은 단어수준에서 수 행되는 표준화검사에 의한 것이다. 표준화검사는 정해진 매뉴얼대 로 검사를 실시하고 결과를 해석하기 때문에 진단가 입장에서는 상대적으로 부담이 덜한 방법이다. 그러면서도 신뢰도와 타당도를 갖추고 있어 그 결과를 신뢰할 수 있고, 다양하고 객관적인 지표를 구할 수 있으면서 진단가 간 의사소통이 용이하고, 치료로 인한 진 전 정도 또한 객관적으로 보여줄 수 있다는 장점이 있다.

이러한 말소리장애의 진단 과정에 있어 가장 큰 역할을 하는 것 중 하나가 말소리발달이다. 말소리발달은 언어적 발달을 반영하는 동시에 운동조절능력과 작업기억능력과 같은 인지적 발달을 전제 한다. 때문에 정상적 또는 비정상적 말소리발달이 시사하는 바는 비단 말소리능력에만 국한되지 않는다. 그뿐만 아니라 진단 후 중 재 여부에 대한 의사 결정에 있어서도 말소리발달은 가장 중요한 기준으로 작용한다. 이처럼 말소리발달은 말소리장애와 관련하여 여러 가지 측면에서 그 중요성이 부각되지 않을 수 없다.

말소리발달과 말소리장애의 진단에 사용되는 지표 가운데 국내 임상현장에서 가장 널리 사용되는 방법은 자음정확도(percentage of consonants correct, PCC)이다. PCC는 왜곡반응을 오류에 포함 시키는지 여부에 따라 PCC와 개정자음정확도(percentage of consonants correct-revised, PCC-R)로 구분된다. PCC는 왜곡오류까 지 민감하게 평가해주는 지표인 반면, PCC-R은 비교적 전반적인 중증도를 잘 반영하는 지표로 활용된다. 또한 단어단위 음운발달 지표인 평균음운길이(phonological mean length of utterance, PMLU)와 단어단위근접률(proportion of whole-word proximity, $\mathrm{PWP})$ 은 분절음의 산출과 오류뿐 아니라 음절길이에 따른 수행력 를 평가해 주기 때문에, 전체 단어 또는 어절의 구조를 형성하는 능 력에 대한 정보를 제공한다. 더불어 단어단위정확률(proportion of whole-word correctness, PWC)은 성인과 동일한 형태의 단어 또는 어절을 얼마나 많이 산출하는지를 평가해 주기 때문에, 단어단위 의 음운능력에 대한 전반적인 수행수준을 가늠하게 해준다. 이처 럼 말소리발달 수준과 장애 정도를 나타내주는 지표들이 점점 다 양해지고 있다. 말소리장애의 특성을 더 잘 이해하고 정확하게 평 가하기 위해, 말소리 산출능력을 타당하고 민감하게 반영해 줄 수 있는 객관적인 지표에 대한 지속적인 고민과 개발이 계속되고 있다 (Kim \& Ha, 2018).

국내에서는 이러한 지표들에 대한 연령별 발달 규준은 주로 말 소리장애 검사도구의 표준화 과정에서 조사되었고 그 결과물이 임 상현장에 제공되었다. 임상현장에서 사용되고 있는 대표적인 표준 화 검사도구로는 우리말 조음·음운평가(Urimal Test of Articulation and Phonology, U-TAP; Kim \& Shin, 2004), 아동용 발음검사
(Assessment of Phonology and Articulation for Children, APAC; Kim, Pae, \& Park, 2007), 한국어 표준 그림 조음음운검사(Korea Standard Picture of Articulation and Phonological Test, KS-PAPT; Seok, Park, Shin, \& Park, 2008)가 있다. 이 검사도구들에도 발달규 준이 제시되어 있으나, 제공된 규준자료들은 서울·경기지역 또는 대구지역 등 제한된 지역에서 자료가 수집된 것일 뿐 아니라 집단 별 인원이 매우 제한적인 수준으로 전국적으로 일반화시키는 데에 는 한계가 있다. 표준화 연구뿐 아니라 말소리장애 지표와 관련된 선행연구들에서도 연령과 성에 따른 지표값의 차이를 보여주었지 만, 지역 및 수적 한계로 인해 일반아동들의 말소리발달 단계에 대 한 확실한 모형을 제공하지는 못하고 있는 실정이다. 따라서 보다 다양한 지역에서 충분한 대표성을 갖는 아동을 대상으로 한 연령 별 말소리발달 지표에 대한 규준이 요구된다. 이러한 필요성에 의 해 개발되기 시작한 UTAP2는 2세 후반부터 7세까지 말소리발달 의 전 연령대 아동들을 규준 집단에 포함시켰고, 특히 2 세 6 개월부 터 5 세 11 개월까지는 연령을 6 개월 단위로 나누어 집단을 세분화 함으로써 그 발달 과정을 민감하게 제시하고자 하였다. 또한 연령 별 집단 크기를 100 명 이상으로 하였고, 내용타당도, 구인타당도, 공인타당도, 발달적 타당도, 문항내적일치성 신뢰도, 반분신뢰도, 검사-재검사 신뢰도에 대해 높은 타당성과 신뢰성을 보여주었다 (Kim et al., 2018).

본 연구의 목적은 국내의 광범위한 지역에서 연령별로 충분한 수 의 아동을 대상으로 수집된 UTAP2의 단어검사에 대해 다양한 말 소리발달 지표로 그 수행력을 측정하여 결과를 비교함으로써, 포 괄적인 말소리발달 단계의 모형을 제시하고자 하는 것이다. 이를 위 해 말소리발달 지표로 PCC, PCC-R, PWC, PMLU, PWP을 사용 하였으며, 각 지표들에서 일반아동의 수행력이 성별 및 연령에 따 라 통계적으로 유의한 차이를 보이는지, 그리고 구체적으로 어떤 집단 간에 유의한 차이가 나타나는지를 알아보았다.

\section{연구방법}

\section{연구대상}

$\mathrm{UTAP} 2$ 의 규준작업을 위하여 서울경기, 충청도, 경상도, 전라도 의 각 지역에서 연구자 1 인이 독자적으로 연구팀을 구성하였다. 각 연구팀은 2018년 5월부터 9월까지 약 5개월간 해당 지역에서 2세 후반부터 7세까지의 일반아동들을 모집하였다. 어린이집, 유아원, 유치원, 영유아 대상의 학원, 학교, 지인의 가정 등 기관과 장소를 제한하지 않았으나, 언어치료실, 특수기관, 재활기관 등 일반적으 로 발달하지 않는 아동들을 대상으로 하는 기관은 제외하였다. 모 
든 대상자들에게 사전 검사로 수용·표현어휘력검사(Receptive \& Expressive Vocabulary Test, REVT; Kim, Hong, Kim, Jang, \& Lee, 2009)를 실시하여, 수용어휘력이 -2 SD 미만인 아동은 연구대상에 서 제외하였다. 이후 4 개 연구팀이 수집한 전체 데이터에 대해 줄기잎 그림(stem-and-leaf plot) 분석을 실시하여, 검사에 참여하였으 나 UTAP2의 단어수준 검사에서 말소리 산출능력 지표값이 극단 치(outliers)를 나타낸 대상자들을 규준 대상에서 제외하였다.

검사에 참여한 전체 인원은 651명이었으나, 극단치를 나타낸 31 명을 제외하고 총 620 명이 규준 집단에 포함되었다. 대상자들의 생 활연령은 2세 6개월부터 7세 11 개월에 해당하였으며, 2세 6개월부 터 5 세까지는 6 개월 단위로, 6 세와 7세는 1년 단위로 연령집단을 구 분하였다. Table 1에서 알 수 있듯이 연령집단별 대상자 수는 비교 적 유사하였고, 성별 분포에는 유의한 차이가 없었다 $\left(\chi^{2}=1.282\right.$, $p>$.05). 또한 서울, 경기도, 충청도, 경상도, 전라도, 제주도에 이르 기까지 전국 규모로 규준 대상자들을 모집하였음을 알 수 있다.

Table 1. Demographic characteristics of study subjects

\begin{tabular}{lcc}
\hline & Number of subjects (\%) & REVT-R (raw sore) \\
\hline Age (yr;mo) & & \\
2;6-2;11 & $66(10.6)$ & $20.60 \pm 9.66$ \\
$3 ; 0-3 ; 5$ & $59(9.5)$ & $27.37 \pm 10.83$ \\
$3 ; 6-3 ; 11$ & $61(9.8)$ & $33.48 \pm 11.07$ \\
$4 ; 0-4 ; 5$ & $82(13.2)$ & $43.22 \pm 12.90$ \\
4;6-4;11 & $73(11.8)$ & $49.81 \pm 10.89$ \\
$5 ; 0-5 ; 5$ & $62(10.0)$ & $57.03 \pm 11.68$ \\
$5 ; 6-5 ; 11$ & $72(11.6)$ & $64.67 \pm 9.52$ \\
6;0-6;11 & $91(14.7)$ & $72.03 \pm 11.05$ \\
$7 ; 0-7 ; 11$ & $54(8.7)$ & $87.17 \pm 13.93$ \\
Total & $620(100)$ & $51.05 \pm 22.83$ \\
Gender & & \\
Male & $303(48.9)$ & - \\
Female & $317(51.1)$ & - \\
Total & $620(100)$ & - \\
Location & & - \\
Seoul & $102(16.5)$ & - \\
Gyeonggi-do & $95(15.3)$ & - \\
Chungcheong-do & $88(14.2)$ & - \\
Gyeongsang-do & $146(23.5)$ & - \\
Jeolla-do & $159(25.6)$ & - \\
Jeju-do & $30(4.8)$ & - \\
Total & $620(100)$ & - \\
\hline
\end{tabular}

REVT-R=Receptive \& Expressive Vocabulary Test-Receptive vocabulary (Kim, Hong, Kim, Jang, \& Lee, 2009).

aValues are presented as number $(\%)$ or mean \pm SD.

\section{검사 도구}

본 연구에 사용한 검사도구는 UTAP2의 단어수준 검사이다. $\mathrm{UTAP} 2$ 의 단어수준 검사는 그림을 보고 이름을 말하는 과제를 통 하여 총 30 개의 단어에 포함된 전체 말소리의 산출능력을 평가하 도록 되어 있다. 기존 U-TAP의 제한점들을 보완하여 명명일치도, 그림타당도 등을 갖춘 현실적이고 대표적인 그림자극을 제작하였 고(Kim et al., 2018), 어두초성, 어중초성, 어중종성, 어말종성의 네 위치에서 우리말 19 개의 자음이 골고루 출현하고 아동들에게 친숙 한 단어들을 선정하였다(Appendix 1).

\section{검사 절차}

실험은 아동이 재학하는 기관 또는 거주하는 가정의 조용한 방 에서 일대일로 진행되었다. 모든 대상자에게 사전 검사인 REVT와 본 검사인 UTAP2의 단어수준 검사를 실시하였다. 그림자극을 본 후 그림 이름을 스스로 말하는 대면이름대기 과제가 기본적인 검 사 절차이지만, 나이가 어린 아동, 해당 그림 또는 사물이 익숙하지 않은 아동 등 자발적인 이름대기가 어려운 대상자의 경우 검사틀 에 제시된 의미단서를 제공한 후 이름대기를 유도하였다. 의미단서 후에도 이름대기가 어려운 대상자에게는 검사자의 발음을 그대로 따라하는 따라말하기 절차를 이용하였다. 검사를 진행하면서 대 상자의 반응을 자세히 기록지에 기록하였다. 3 세 이상 아동의 반응 은 오디오 파일로 녹음하고 2세 후반 아동의 반응은 동영상으로 촬영하여, 필요할 경우 오디오 파일 또는 동영상을 재생하여 기록 지의 자료를 보완하였다.

\section{자료분석 및 통계분석}

전산화 자동분석 프로그램인 Korean Speech Sound Analysis Tool (KSAT; Kim, Jang, Hwang, \& Chang, 2016)을 사용하여 말소 리 산출능력에 대한 모든 지표값을 계산하였다. 말소리 산출능력 에 대한 구체적인 분석방법은 다음과 같다.

\section{$\mathrm{PCC}$ 분석}

PCC는 전체 자음에 대해 정확하게 조음한 자음의 비율을 백분 율로 계산한 값이다. UTAP2 단어수준 검사의 전체 30 개의 단어에 포함된 모든 자음(총 94개)에 대해 PCC를 계산하였다. 왜곡반응 을 오류에 포함시켜 계산하는지에 따라, PCC와 PCC-R로 다시 구 분된다. 왜곡반응은 우리말에 존재하지 않은 말소리 형태로 산출 한 오류로, 대부분의 경우 음소경계 내에서 음성학적 변이형으로 발음된 것이기 때문에 의사전달에는 크게 부정적인 영향을 미치기 않아 정조음으로 간주되기도 한다. 이처럼 왜곡반응을 정조음에 
포함하여 계산한 자음정확도가 PCC-R이다.

\section{단어단위 음운지표 분석}

단어단위 음운지표로 PWC, PMLU, PWP를 구하였다. PWC는 전체 발화에서 단어 전체가 정확하게 산출된 비율이 어느 정도인 지, PMLU는 산출된 단어들이 얼마나 복잡한 분절음 구조들로 구 성되었는지, $\mathrm{PWP}$ 는 산출한 발음이 목표단어와 얼마나 유사한지 를 각각 의미한다. PWC는 전체 단어의 수를 분모로, 단어 전체가 정확하게 산출된 수를 분자로 하여 계산되기 때문에, 최대 점수는 1 점, 최저 점수는 0 점이 된다. PMLU는 각 단어에서 산출된 분절음 에 1 점씩, 정확하게 발음된 자음에 추가 1 점씩을 주어 합산한 후, 총 점을 전체 단어수로 나누어 계산한다. 따라서 긴 단어를 발화할수 록, 단어에 포함된 자음을 정확하게 발음할수록 PMLU 수치는 높 아진다. PWP는 대상자의 PMLU를 성인이 정조음한 형태의 PMLU 값으로 나누어 계산하므로, $\mathrm{PWC}$ 와 마찬가지로 최대 점수가 1점, 최저 점수가 0 점이 된다. 단어단위 음운지표에 대한 보다 자세한 설 명과 구체적인 계산 방법에 대한 예시는 Kim과 Shin (2015)을 참고 할수 있다.

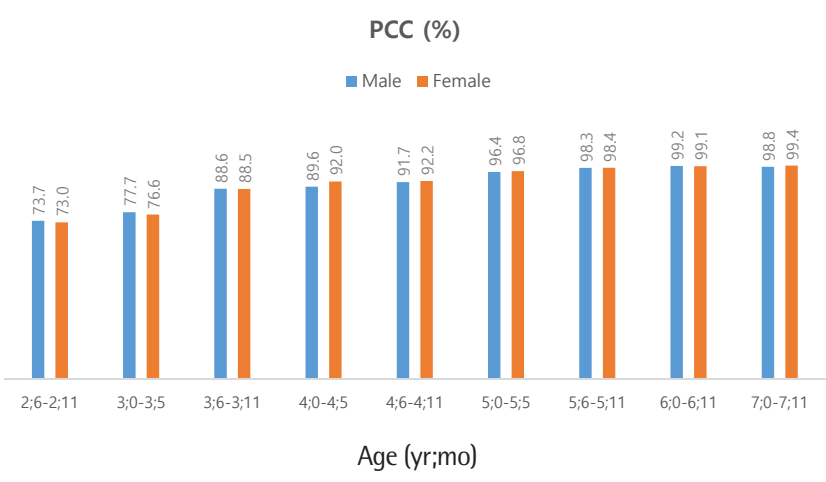

Figure 1. The score of percentage of consonants correct (PCC).

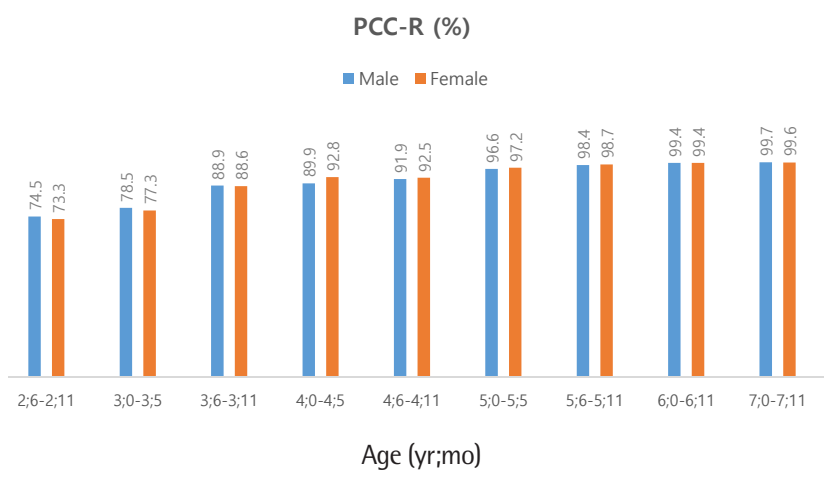

Figure 2. The score of percentage of consonants correct-revised (PCC-R).

\section{통계분석}

자료의 통계처리는 SPSS version 23.0 (IBM, Armonk, NY, USA)를 이용하였다. 각 지표값에 대한 성별 및 연령집단 간 차이 를 알아보기 위해, 유사한 성격의 지표를 반복적으로 측정한 PCC 와 PCC-R에 대해서는 2피험자 간-1피험자 내 혼합설계에 따른 반 복측정분산분석을, 나머지 지표들에 대해서는 이원분산분석을 각각 실시하였다.

\section{연구결과}

\section{성별 및 연령에 따른 PCC와 PCC-R의 비교}

대상자의 연령이 높아짐에 따라 PCC와 PCC-R 점수가 꾸준히 향상되었으나, 성별에 따른 차이는 두드러지지 않았다(Figures 1, 2). 통계분석 결과 PCC와 PCC-R은 연령에 따라 유의한 차이를 보 였지만 $\left(F_{(8,601)}=82.387, p<.001\right)$, 성별에 따른 차이 $\left(F_{(1,601)}=.084\right.$, $p>.05)$, 성별과 연령의 상호작용효과 $\left(F_{(8,601)}=.303, p>.05\right)$ 는 유의 하지 않았다. 연령 간 차이에 대해 Scheffe 사후검정을 실시한 결과, 2 세 후반과 3 세 초반은 3 세 후반 이후, 3 세 후반과 4 세 초반은 5 세 초반 이후, 4 세 후반은 5 세 후반 이후 모든 연령집단보다 유의하게

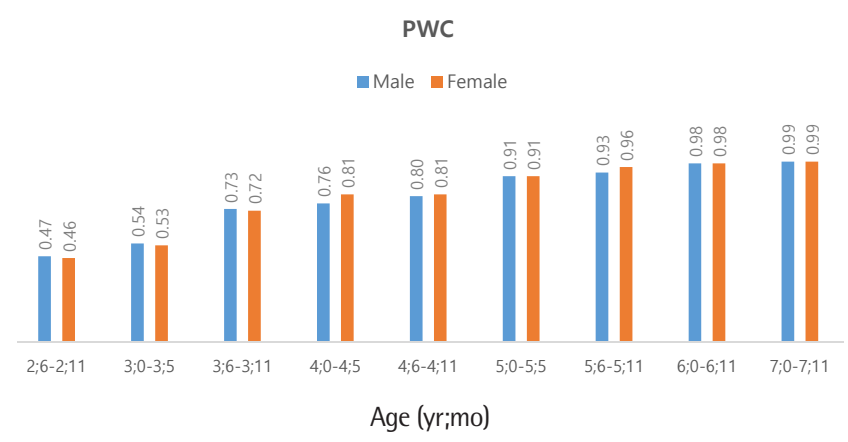

Figure 3. The score of proportion of whole-word correctness (PWC).

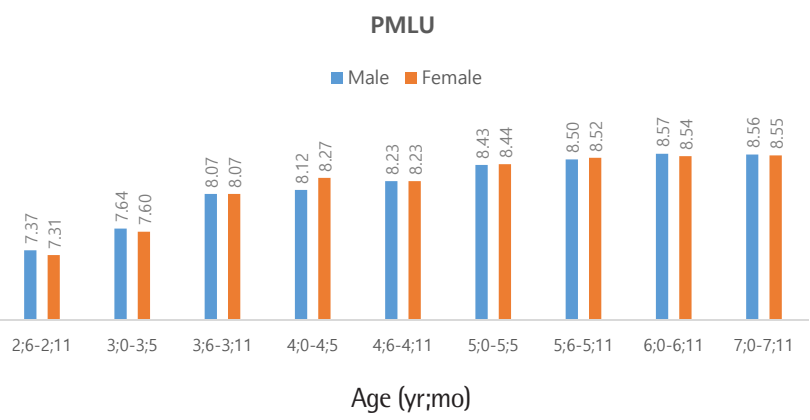

Figure 4. The score of phonological mean length of utterance (PMLU). 


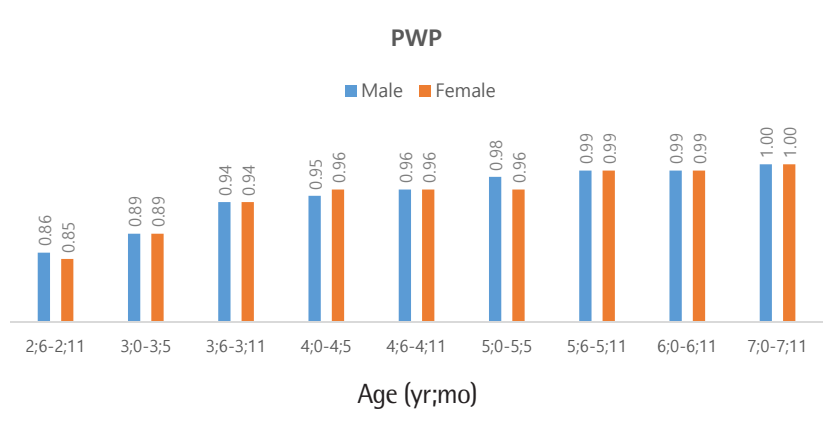

Figure 5. The score of proportion of whole-word proximity (PWP).

점수가 떨어진 반면 $(p<.05), 5$ 세 초반부터는 이후 연령집단들과 유 의한 차이를 보이지 않았다( $p>.05)$. 즉, PCC와 PCC-R의 경우 5세 초반부터 천정효과(ceiling effect)가 나타난다는 것을 알 수 있다.

피험자 내 주효과 검정 결과 왜곡의 오류처리 여부에 따라 정확 도에 유의한 차이를 보여 $\left(F_{(1,601)}=47.735, p<.001\right)$, 왜곡을 오류로 처리하지 않은 PCC-R에서 점수가 유의하게 높은 것으로 나타났다. 그러나왜곡처리 여부와 연령 간 상호작용효과 $\left(F_{(8,601)}=1.173, p>.05\right)$, 왜곡처리 여부와 성별 간 상호작용효과 $\left(F_{(1,601)}=.441, p>.05\right)$, 왜곡 처리 여부, 연령, 성별의 삼요인 상호작용효과 $\left(F_{(8,601)}=1.087, p>.05\right)$ 는 모두 유의하지 않았다.

\section{성별 및 연령에 따른 단어단위 음운지표의 차이}

$\mathrm{PWC}, \mathrm{PMLU}, \mathrm{PWP}$ 모든 지표에서 연령이 높아짐에 따라 점수 가 꾸준히 향상되었으나, 성별에 따른 차이는 두드러지지 않았다 (Figures 3-5). 통계분석 결과 세 지표 모두에서 연령 간 차이는 유 의하였지만 $\left(F_{(8,601)}=43.261, p<.001 ; F_{(8,601)}=35.505, p<.001 ; F_{(8,601)}\right.$ $=76.245, p<.001)$, 성별에 따른 차이 $\left(F_{(1,601)}=.366, p>.05 ; F_{(1,601)}=\right.$ $\left..841, p>.05 ; F_{(1,601)}=.091, p>.05\right)$, 성별과 연령 간 상호작용효과 $\left(F_{(8,601)}=.311, p>.05 ; F_{(8,601)}=.929, p>.05 ; F_{(8,601)}=.386, p>.05\right)$ 는 유의하지 않았다. 각 지표에서 연령 간 차이에 대해 Scheffe 사후검 정을 실시한 결과, $\mathrm{PWC}$ 에서는 2 세 후반과 3 세 초반은 3 세 후반 이 후, 3 세 후반과 4 세 초반은 5 세 초반 이후, 4 세 후반은 5 세 후반 이 후, 5 세 초반은 6 세 이후 모든 연령집단들보다 점수가 유의하게 낮 았으나 $(p<.01), 5$ 세 후반부터는 이후 연령집단들과 유의한 차이를 보이지 않았다( $p>.05)$. PMLU의 경우 2세 후반과 3 세 초반은 3 세 후반 이후, 3 세 후반은 5 세 초반 이후, 4 세 초반과 4 세 후반은 5 세 후반 이후, 5 세 초반은 6 세 이후 모든 연령집단들보다 점수가 유의 하게 낮았으나 $(p<.01), 5$ 세 후반부터는 이후 연령집단들과 유의한 차이가 없었다 $(p>.05)$. $\mathrm{PWP}$ 의 경우 2 세 후반과 3 세 초반은 3 세 후 반 이후, 3 세 후반은 5 세 초반 이후, 4 세 초반, 4 세 후반과 5 세 초반
은 5세 후반 이후 모든 연령집단들보다 점수가 유의하게 낮았으나 $(p<.01), 5$ 세 후반부터는 이후 연령집단들과 유의한 차이가 없었 다( $p>.05)$.

\section{논의 및 결론}

본 연구에서는 U-TAP의 개정판인 UTAP2의 단어수준 검사를 이용하여 성별과 연령에 따른 말소리 산출능력의 지표값들의 차이 를 비교하였다. 그 결과 모든 지표에서 성별의 차이는 유의하지 않 았으나 연령집단별 차이는 유의하였고, 구체적으로는 PCC와 PCC-R 의 경우 4 세 후반까지, 단어단위 음운지표의 경우 5 세 초반까지 연 령에 따라 유의한 변화가 관찰되었다. 또한 모든 연령집단에서 왜 곡반응을 오류로 처리한 PCC보다 정조음으로 처리한 PCC-R에서 유의하게 점수가 높았다. 이는 왜곡반응을 정반응으로 간주하여 점수를 부여하였기 때문에 나타난 당연한 결과이나, 그보다는 2 세 후반에서 7세의 전 연령에 걸쳐 왜곡반응이 출현한다는 것에 주목 할 필요가 있다.

단어단위 음운지표에 대한 결과를 좀 더 심층적으로 논의하기에 앞서, 음운발달에 대한 선행연구들을 살펴보면 초기 음운발달이 일어나는 시기는 첫 단어부터 단어조합이 시작되는 1-2세라는 점 에는 모든 연구자들이 동의하고 있다. 이후 2 세 후반 이후 6 세까지 를 ‘후기 발달시기’로 정의한 연구를 찾아볼 수 있는데(Kim \& Shin, 2015), 이 시기 전체를 말소리발달에 있어 포괄적인 한 단계로 정의 하기에 다소 무리가 있다. 따라서 본 연구결과에서 얻은 각 지표의 평균값과 집단 간 차이에 대한 검정결과를 근거로 하여, 후기 발달 시기를 좀 더 세부적으로 나누어 보고자 한다. 이에 앞서 말소리발 달 단계를 보다 세부적으로 분류한 선행연구들을 살펴보면, Ingram과 Ingram (2001)은 PMLU를 기준으로 초기 말소리발달을 6 단계로 제안하였다. 즉, 자발화에서 PMLU가 $3,4,5,6,7$ 에 이르는 시기를 각각 1 부터 5 단계로, PMLU 8 이상인 시기를 6 단계로 보았 는데, PMLU가 8 이상이 되면 상대적으로 PMLU 정보는 덜 중요한 것으로 간주하였다. 한국 아동을 대상으로 자발화에서 단어단위 음운지표를 분석한 Yoon, Kim과 Kim (2015)의 연구에서는, PMLU 가 2 세는 약 6,3 세 전반은 7,4 세 전반은 8 로 늘어난다고 하였다. 이 는 미국 일반아동의 PMLU 발달과 유사한 수준이다. 그러나 본 연 구는 단어수준에서 말산출을 유도하여 분석을 실시한 것이기 때 문에, 자발화를 기반으로 한 선행연구들의 PMLU 수치와는 다소 다른 결과를 보였다. 본 연구에서는 PMLU가 2세 후반과 3세 전반 까지는 약 7, 3세 후반부터 5세 전반까지 8-8.5, 5세 후반 이후에는 8.5 이상으로 나타나, 선행연구보다 전반적으로 높은 수치를 보였 
다. 분석한 자료의 종류에 따라 말소리 지표의 수치는 어느 정도 달 라질 수 있으므로, 동일하지 않은 자료들로부터 얻은 분석결과들 을 직접 비교할 때에는 주의를 기울여야 할 것이다.

본 연구결과 PMLU, PWC, PWP와 같은 단어단위 지표는 5세 초 반까지 유의한 변화를 보이다가 5 세 후반에 이르러 성인의 말소리 형태에 $99 \%$ 이상 근접하게 됨에 따라(Figure 5), 이후 연령집단과 더 이상 차이를 보이지 않았다. 자음의 정확도와 더불어 분절음들 을 조합하여 전체 단어를 형성하는 능력은 각 분절음을 정확하게 조음하는 능력 외에도 부가적인 음운적 처리능력까지 요구되기 때 문에 5세 후반에 이르러서야 성인과 유사한 정도로 완성됨을 알 수 있다. 또한 단어단위 음운지표는 통단어 형태로 어휘를 습득하는 초기 말소리발달 수준을 평가하기에 적합한 것으로 보고된 바 있 으나(Yoon et al., 2013), 본 연구결과는 후기 말소리발달을 민감하 게 평가하는 데에도 적절한 지표임을 시사한다. 또한 PCC의 천정 효과가 나타나는 연령이 단어단위 음운지표와는 다소 차이가 있었 는데, PCC와 PCC-R의 경우 4세 후반까지는 연령집단 간 점수에 유의한 변화가 있었으나 5 세 초반 $96 \%$ 이상의 높은 정확도를 보이 기 시작한 이후 연령집단 간 차이가 더 이상 유의하지 않았다.

본 연구는 전국적인 규모에서, 표준화 검사가 가능한 가장 어린 연령대인 2 세부터 학령기에 해당하는 만 7세까지 말소리발달 전반 을 아우르는 넓은 연령대를 대상으로 하였으며, 연령집단을 1 년을 단위로 하지 않고 전반과 후반으로 나누어 보다 세밀한 연령으로 구분하고 다양한 말소리 평가지표를 사용하여 동일한 대상자의 말 소리 산출능력을 평가, 비교함으로써 분절음과 음운 차원의 수행 력을 비교하였다는 점에서 의의가 있다. 따라서 이 연구결과를 바 탕으로 전반적인 우리말 습득 단계에 대한 모형을 도출해 볼 수 있 는 기초작업이라고 할 수도 있을 것이다. 우선은 단어수준에서 결 과를 종합해 볼 때, 2 세 후반부터 6 세까지의 연령에 대해 다음과 같 이 세 개의 말소리발달 하위 단계로 나누어 볼 수 있을 것이다. 첫 째, 2세 후반부터 3세 초반까지 '말소리 목록의 확장기'를 거친다. 둘째, 3 세 후반부터 4 세 후반까지 말소리가 정확해지면서 음절구조 를 복잡하고 길게 산출할 수 있는 '말소리 정교화기'를 지난다. 셋 째, 5세 초반부터 '말소리 습득 안정기'로 진입하여 이후 연령에서 는 모든 지표에서 천정효과를 보이게 됨에 따라 성인과 같은 수준 의 말소리 수행수준을 보인다. 물론 검사대상에 포함되지 못한 1 세 부터 2 세초반까지 초기 말소리 발달기는 매우 중요한 시기로 '말소 리 생성기'라고 할 수 있을 것이다(Moon \& Ha, 2012). 다시 정리해 본다면 우리 말소리 습득 단계는 말소리 생성기(1-2세 초반), 확장기 (2세 후반-3세 초반), 정교화기(3세 후반-4세 후반), 안정기(5세 초 반-6세)에 이르러 성인의 형태와 유사해진다는 것이다.
이후 연구에서는 단어 수준을 넘어서서 문장 과제 혹은 자발화 에서도 음운발달 양상에 대한 모형을 구축해 보기 위한 노력이 필 요하다. 대상자에 따라, 특히 장애를 보이는 대상자의 경우에는 어 떤 평가지표를 선택하는가, 어떤 문맥에서 평가되어졌는가에 따라 검사자가 얻게 되는 정보 또한 달라진다(Kim \& Shin, 2015). 따라 서 진단가들에게 필요한 다양한 평가문맥에서의 발달 양상에 대 한 준거 자료를 제공하기 위한 연구들이 계속 필요하다.

\section{REFERENCES}

American Speech-Language-Hearing Association (n.d.). Speech sound disorders-articulation and phonology. https://www.asha.org/Practice-Portal/ Clinical-Topics/Articulation-and-Phonology/

Bernthal, J. E., Bankson, N. W., \& Flipsen, P. (2013). Articulation and phonological disorders: speech sound disorders in children (7th ed.). Boston, MA: Pearson.

Ingram, D., \& Ingram, K. D. (2001). A whole-word approach to phonological analysis and intervention. Language, Speech, and Hearing Services in Schools, 32(4), 271-283.

Kim, M., \& Ha, S. (2018). Developing weighted phonological mean length of utterance and testing the validity. Communication Sciences \& Disorders, 23(3), 692-702.

Kim, M. J., Pae, S., \& Park, C. I. (2007). Assessment of Phonology and Articulation for Children (APAC). Incheon: Human Brain Research \& Consulting Co.

Kim, S. J., Jang, K. W., Hwang, D. H., \& Chang, M. S. (2016). Development of Korean Speech Sound Analysis Tool (KSAT). Proceedings of the 2016 Fall Conference of the Korean Society of Speech Sciences (KSSS), 121-122.

Kim, S. J., \& Shin, J. Y. (2015). Speech sound disorders. Seoul: Sigmaprss.

Kim, Y. T., Hong, G. H., Kim, K. H., Jang, H. S., \& Lee, J. Y. (2009). Receptive \& Expressive Vocabulary Test (REVT). Seoul: Seoul Community Rehabilitation Center.

Kim, Y. T., Park, H., Kang, J. K., Kim, J. A., Shin, M. J., Kim, S. J., \& Ha, J. W. (2018). Validity and reliability analyses for the development of Urimal Test of Articulation and Phonology-2. Communication Sciences \& Disorders, 23(4), 959-970.

Kim, Y. T., \& Shin, M. J. (2004). Urimal test of articulation and phonology (UTAP). Seoul: Hakjisa.

Moon, H., \& Ha, S. (2012). Phonological development in toddlers with cleft palate and typically developing toddlers aged 12-24 months. Communica- 
tion Sciences \& Disorders, 17(1), 118-129.

Seok, D. I., Park, S. H., Shin, H. J., \& Park, H. J. (2008). The Korea Standard

Picture of Articulation and Phonological Test (KS-PAPT). Seoul: Hakjisa.
Yoon, M. S., Kim, J. M., \& Kim, S. J. (2013). Phonological whole-word measures of spontaneous speech in children two to four years of age. Journal of Speech-Language \& Hearing Disorders, 22(4), 69-85. 
Ji-Wan Ha, et al. • Developmental Analysis in Korean Children's Speech

Appendix 1. Test items of the word-level subtest in UTAP2

\begin{tabular}{|c|c|c|c|c|c|c|c|}
\hline 번호 & 목표 단어 & 목표 발음 & 발음 전사 & 번호 & 목표 단어 & 목표 발음 & 발음 전사 \\
\hline 1 & 나무 & 나무 & & 16 & 단추 & 단추 & \\
\hline 2 & 목도리 & 목또리 & & 17 & 곰 & 곰 & \\
\hline 3 & 胘 & 꼳 & & 18 & 가방 & 가방 & \\
\hline 4 & 김밥 & 김빱 & & 19 & 똥 & 똥 & \\
\hline 5 & 바지 & 바지 & & 20 & 책상 & 책쌍 & \\
\hline 6 & 사탕 & 사탕 & & 21 & 자동차 & 자동차 & \\
\hline 7 & 풍선 & 풍 선 & & 22 & 빨간(강)색 & 빨 간(강) 색 & \\
\hline 8 & 국자 & 국 짜 & & 23 & 짹짹 & 짹 짹 & \\
\hline 9 & 토끼 & 토끼 & & 24 & 그네 & 그 네 & \\
\hline 10 & 코끼리 & 코끼리 & & 25 & 기차 & 기차 & \\
\hline 11 & 해바라기 & 해바라기 & & 26 & 접시 & 접씨 & \\
\hline 12 & 연필 & 연(염) 필 & & 27 & 로봇(로보트) & 로 볻(로 보 트) & \\
\hline 13 & 호랑이 & 호랑이 & & 28 & 싸움 & 싸움 & \\
\hline 14 & 라면 & 라면 & & 29 & 짜장면 & 짜장면 & \\
\hline 15 & 냉장고 & 냉장고 & & 30 & 포크 & 포크 & \\
\hline
\end{tabular}

UTAP2=Urimal Test of Articulation and Phonology second edition. 


\section{국문초록}

\section{자음정확도와 단어단위 음운지표를 이용한 일반아동의 말소리 산출능력에 대한 발달 연구}

하지완 ${ }^{\prime}$ 김수진 ${ }^{2} \cdot$ 김영태 $^{3} \cdot$ 신문자 ${ }^{4}$

'대구대학교 언어치료학과, ${ }^{2}$ 나사렛대학교 언어치료학과, ${ }^{3}$ 이화여자대학교 언어병리학과, ${ }^{4}$ 조선대학교 언어치료학과

배경 및 목적: 본 연구의 목적은 국내의 광범위한 지역에서 연령별로 충분한 수의 아동들에 대해 다양한 말소리발달 지표로 말소리 산 출능력을 측정한 후 그 결과를 비교함으로써, 포괄적인 말소리발달 단계의 모형을 제시하고자 하는 것이다. 방법: 서울, 경기도, 충청도, 경상도, 전라도 및 제주도 지역의 2 세 후반부터 7세까지 일반아동들에게 UTAP2의 단어수준 검사를 실시하였다. 자음정확도, 개정자 음정확도, 단어단위정확률, 평균음운길이, 단어단위근접률의 다양한 지표를 이용하여 아동들의 말소리 산출능력을 평가하였다. 2 세 후반부터 5 세까지는 6 개월 단위로, 6 세와 7 세는 1 년 단위로, 연령을 9 개의 집단으로 구분한 후, 각 말소리지표에 대해 연령집단과 성별 에 따른 차이를 비교하였다. 결과: 모든 지표에서 성별에 따른 차이는 유의하지 않았으나, 연령 간 차이는 유의한 것으로 나타났다. PCC 와 PCC-R은 4세 후반까지, 단어단위 음운지표들은 5 세 초반까지 연령이 높아짐에 따라 지표값들도 유의하게 향상되었다. 논의 및 결 론: 본 연구와 선행연구 결과들을 종합하여, 1 세부터 2 세 초반까지 ‘말소리 생성기', 2 세 후반부터 3 세 초반까지 '말소리 목록 확장기’, 3 세 후반부터 4 세 후반까지는 ‘말소리 정교화기’, 5 세 초반부터 6 세까지는 ‘말소리 습득 안정기’로 말소리발달 모형을 제안하고자 한다.

핵심어: 말소리발달, 유탭2, 연령별 규준, 자음정확도, 단어단위정확률, 평균음운길이, 단어단위근접률

본 논문은 2017년 정부(교육부)의 재원으로 한국연구재단의 지원을 받아 수행된 연구임(No. NRF-2017R1C1B1010913).

\section{참고문헌}

김민정, 배소영, 박창일(2007). 아동용 발음평가(APAC). 인천: 휴브알앤씨.

김민정, 하승희(2018). 가중평균음운길이의 개발과 타당도 검증. Communication Sciences \& Disorders, 23(3), 692-702.

김수진, 신지영(2015). 말소리장애. 서울: 시그마프레스.

김수진, 장기완, 황득하, 장문수(2016) 한국어말소리평가프로그램(KSAT)의 개발. 한국음성학회 가을학술대회 발표논문집, 121-122.

김영태, 박희영, 강진경, 김정아, 신문자, 김수진, 하지완(2018). 우리말 조음·음운평가-2(UTAP-2) 개발을 위한 타당도 및 신뢰도 분석. Communica-

tion Sciences \& Disorders, 23(4), 959-970.

김영태, 신문자(2004). 우리말 조음·음운평가(U-TAP). 서울: 학지사.

김영태, 홍경훈, 김경희, 장혜성, 이주연(2009). 수용·표현어휘력검사(REVT). 서울: 서울장애인종합복지관.

문희원, 하승희(2012). 12-24개월 구개열 유아와 일반 유아의 음운발달. 언어청각장애연구, 17(1), 118-129.

석동일, 박상희, 신혜정, 박희정(2008). 한국어 표준 그림 조음음운 검사(KS-PAPT). 서울: 학지사.

윤미선, 김정미, 김수진(2013). 자발화 문맥에서의 단어단위 음운평가. 언어치료연구, 22(4), 69-85.

\section{ORCID}

하지완(https://orcid.org/0000-0002-1191-791X); 김수진(https://orcid.org/0000-0002-9354-8504);

김영태(https://orcid.org/0000-0003-1738-6862); 신문자(https://orcid.org/0000-0003-3279-7221) 